\title{
ZOPPOLA, ZOPPOLANI AND MIGRATION TO WESTERN CANADA: A SAMPLE STUDY
}

\author{
Gabriella COLUSSI ARTHur
}

\begin{abstract}
Summary: This paper investigates the departures and arrivals of a group of Zoppolani, Italians from the northeast of Italy who travelled through Ellis Island to British Columbia in search of work between 1906 and 1923. Zoppola is a municipality located in the center west of the autonomous Friuli Venezia-Giulia Region in northeast Italy, and it is approximately $90 \mathrm{~km}$ northwest of Friuli Venezia-Giulia's capital city of Trieste. It was one of many northern Italian towns from which migrants to North America originated. However, little is known of the considerable number of Zoppolani who left the area in the early 1900s and made their way to western Canada. This sample study examines the historical scholarship in the field, considers challenges posed by a variety of archival records and argues that an understanding of the local geography and history of both the comune of Zoppola and the province of British Columbia is essential to the overall interpretation of the emigrant history discussed.
\end{abstract}

\section{Introduction}

This study focusses on the departures and arrivals of a group of Zoppolani, ${ }^{1}$ Italians from the northeast of Italy who, between 1906 and 1923 travelled through Ellis Island, the USA's northeastern gate, to British Columbia, Canada's western-most province, in search of work. Zoppola, located in the center west of the autonomous region of Friuli VeneziaGiulia in northeast Italy, is a municipality (comune) approximately $9 \mathrm{~km}$ east of the city of Pordenone and $90 \mathrm{~km}$ northwest of Friuli VeneziaGiulia's capital city of Trieste. It is one of many northern-Italian towns from which emigrants to North America originated. However, little is known of the considerable number of Zoppolani who left the area in the early 1900s and made their way to western Canada.

Beginning with a review of the scholarship in the field, this study considers methodological aspects of working with archival records, in particular, those in the collection known as the Ellis Island ships' manifests, and argues that an understanding of the local geography and history of Zoppola

${ }^{1}$ An Italian adjectival noun designating those who originate from Zoppola. 
as a place of origin is essential to the overall interpretation of the emigrant history from this region. After a survey of the recent and most pertinent scholarship in the field of North American immigration history the opening section also presents the records, and the information they contain, as the sample upon which this study is based. This analysis, including a discussion of the challenges in these sources, helps to contextualize the research. The second part of the study presents the information extracted from the ships' manifests and includes a discussion of the information the sample offers such as orthographic challenges and spelling variations, the number of migrants according to the year of travel, vessels and ports of departure, and travel companions or travel clusters. The section ends with some questions about challenging narratives and possibilities for future research.

Historians of Italian emigration generally agree that Italians migrated from 1876 to 1976 - the century of Italian-government record-keeping of departures-in three main phases: (1) 1876-1914, the "classic period" during which over $50 \%$ of the total emigration occurred; (2) 1915-1945, the "low emigration" period spanning the two world wars and; (3) 1946-1976, the wave of "renewed migration," accounting for $25 \%$ of the accepted overall total of 26 million. ${ }^{2}$ Emigration was not homogeneous; rather, it varied over time in terms of types of migrations, modalities, volume, intensity, sources and destinations. ${ }^{3}$ The points of origin in Italy are best grouped in three geo-political areas: the North (Piemonte, Liguria, Lombardia, FriuliVenezia Giulia and Veneto); the Center (Toscana, Emilia-Romagna, Lazio, the Marche and Umbria) and the South (Campania, Abruzzo, Molise (formerly Abruzzi-Molise), Puglia, Basilicata (formerly Lucania), Calabria, Sicilia and Sardegna). Records indicate that over the period 1876-1976 some $40 \%$ of departures occurred from the North, $20 \%$ from the Center and $40 \%$ from the South. Of these, 52\% migrated to Europe and almost all of the remainder (44\%) to the Americas including 6 million to North America (90\% to the USA) and 5 million to South America. ${ }^{4}$ This emigration was also characterized by a high rate of return migration, with figures showing that at least 8.5 million returned home.

The Ellis Island records document the movement of a group of

2 Vecoli, “The Italian Diaspora," 114-122. Of course, Vecoli, Gabaccia and others note that emigration should not be limited to this hundred-year period.

3 Ercole Sori, cited in Vecoli, “The Italian Diaspora," 114.

4 Vecoli, "The Italian Diaspora," 114. Emigration to other destinations was almost negligible; namely, $2 \%$ to Africa and $1.5 \%$ to Oceania, mainly Australia. 
Zoppolani who sojourned to British Columbia in search of work between 1906 and 1923 by means of trans-Atlantic journeys to Ellis Island in the USA. Located in the center west of the autonomous region of Friuli-Venezia Giulia, 5 Zoppola is the name given to both the town and the municipality (comune) located approximately $9 \mathrm{~km}$ east of the provincia 6 of Pordenone and $90 \mathrm{~km}$ northwest of the region's capital city, Trieste. During the last decades of the nineteenth and into the early twentieth century, Zoppola was one of the many northern Italian towns from which people emigrated. Little is known, however, about the emigration of this particular group.

\section{Scholarship in the field}

Formal scholarship documenting the lives of Zoppolani is scarce and what is available are publications such as those produced either by the local municipal government in Zoppola, or similar authors, in which emigration from the area is acknowledged and the lives of emigrants are presented anecdotally through stories drawn from their experiences. Two such works are Cent'anni di Zoppola7 (A Hundred Years of Zoppola's History) in which the introductory chapter, Il Novecento Zoppolano nella storia friulana (Zoppola during Friuli's Twentieth century), refers to the movement of those from Zoppola to Argentina at the end of the 1800s. A volume produced by the EFASCE Pordenone ${ }^{8}$ titled 100 Anni con gli emigranti, 19072007 (100 Years with the Emigrants, 1907-2007), ${ }^{9}$ provides a collection of written accounts and photographs by clergy or local social club representatives presenting the stories of emigrant Pordenone communities in North and South America and various destinations in Europe. One of these chapters, for example, presents the Zoppola Social Club of Toronto and the circumstances around which the club was begun in 1968. The EFASCE Pordenone currently maintains an active website and produces a newslet-

5 Located in the northeast corner of Italy; one of the country's twenty administrative regions.

6 A term which does not translate as "province," but rather an administrative ward encompassing a cluster of municipalities

7 La pro loco, editore, Cent'anni di Zoppola.

8 The term EFASCE translates as Friulian Social and Cultural Emigrant Aid Society. It was founded by the local Catholic Action Diocesan Committee in 1907 and, since 1968, is based in Pordenone. It has been shepherded and supervised by the Catholic Action Society and its link with local dioceses and emigrant clergy over the course of its history.

9 EFASCE Pordenone, 100 Anni con gli emigranti 1907-2007. 
ter and other publications documenting emigrant Pordenone communities, ${ }^{10}$ the latter referred to as Pordenonesi nel mondo (Pordenonians ${ }^{11}$ around the world). Also, the organization representing the region of Friuli outside Italy called Ente Friuli nel mondo ${ }^{12}$ publishes regular newsletters, announcements and brochures documenting the lives of emigrant Friulians outside of Italy. Its library-comprising encyclopedias, dictionaries, Friulian-language course texts, drama, Friulian-language prose and poetry, art exhibit catalogues, art and artisanal texts-is also replete with "histories" of Friulians around the world and is an invaluable source of stories (many as works of literature) and photographs from past and current lives of Friulian emigrants. ${ }^{13}$

Academic scholarship in the field ranges from broad perspectives on emigrants from the Region of Friuli-Venezia Giulia (FVG) or Italians from the "national" perspective to specific town-centered emigration of particular Friulian communities. ${ }^{14}$ For the purposes of this paper, the work of Javier Grossutti is significant in that he has examined emigration from FVG both from a broader perspective, namely first to the USA and then to Canada, and from the perspective of particular towns. One such town study is a detailed account titled I Pozzuolesi nel mondo, 15 those who emigrated from Pozzuolo del Friuli, a comune in the provincia of Udine. Working in collaboration with Elisabetta Degano, Grossutti has written a detailed account based on a variety of sources. ${ }^{16}$

Degano and Grossutti included both first-generation emigrants and

10 www.efasce.it

11 Pordenonese (it) Pordenonian (Eng,). The translation here is based on adjectival model "canadese > Canadian."

12 Loosely translated as "The World Friuli Society" or "The Friuli Abroad Society."

13 For a full list of publications see the link Biblioteca in the horizontal menu of the Ente's main page at www.friulinelmondo.com

14 See, for example, Peressini, Migration, Famille et Communauté; Iuele-Colilli, I friulani di Sudbury; Principe and Zorzi Pugliese, Rekindling Faded Memories; and Eisenbichler, ed., An Italian Region in Canada.

15 www.comune.pozzuolo.udine.it/web/uploads/pozzuolesi/www.tommasomazzoli.it/pozzuolo/index.html

16 Grossutti’s sources include municipal registry office records (family, emigration, and immigration forms), the Italians Abroad registry to determine where the Pozzuolesi resided, and personal emigration history forms filled out directly by Pozzuolesi abroad. 
their descendants as part of a larger project that attempts to define the characteristics of communities of Friulian emigrants abroad, including their children and grandchildren. Grossutti's focus is the hometown of origin since it is precisely hometown loyalty which is significant for these Friulian emigrants. As will be discussed below, Grossutti's argument on the significance of the hometown and the comune of origin is compelling and not simply because it frames an understanding of the emigrants' loyalty and identity, but also because of the implications for emigration historians and their interpretation of archival records.

Grossutti's work on emigration from FVG to the USA examines those who emigrated as specialized workers and enjoyed "special status" as emigrant workers. These specialized trades emerged from the tradition of "mosaic and terrazzo floor workers in the pre-alpine area of the region of Carnia"17 who became highly sought after and famous in large American cities such as New York, Philadelphia, and Washington, D.C. because they introduced the Venetian battuto ${ }^{18}$ to North America. The main places of origin for these immigrants were settlements like Sequals and "other villages in the alpine valleys such as Fanna, Meduno and Arba." 19 Grossutti reports evidence of Friulians forming one village and congregating together in certain destinations to work in "steel mills ... steel factories ... or in the mosaic and terrazzo sector as builders." 20 He notes, for example, that in the 1920s and 1930s in San Francisco, the largest group was formed by a number of families from both east and west of the Tagliamento River, including Zoppolani. What Grossutti seems to suggest is that those from Zoppola were not, in fact, specialized workers as were the majority of those from the east of the Tagliamento. Both Grossutti's work on Canada and the records used for the current study suggest that Zoppolani who ventured to Canada's western frontier self-identified as "labourers" while a much smaller number identified as miners. Moreover, from 1906 to 1920 and unlike New York, Washington, Philadelphia or San Francisco, most of British Columbia, was still a rural, natural-resource frontier perhaps with the exception of Vancouver, its emerging metropolitan centre.

\section{Grossutti, Emigration from Friuli-Venezia Giulia towards the United States.}

18 The Venetian battuto or (battuto alla veneziana) is one of the oldest types of floors used in architecture and its roots can be traced to the ancient Roman school of mosaics (rudus novum). See www.cancian pavimenti.it/battuto-allaveneziana for a history of the technique.

19 Grossutti, Emigration, 8.

20 Grossutti, Emigration, 16. 
Grossutti's study of emigration from FVG to Canada begins in the last quarter of the nineteenth century when, for example, Canadian government officials wrote pamphlets appealing to workers and promoting Canada as a land of vast opportunity. He notes that departures were arranged from the Gare St. Lazare train station in Paris to Le Havre, a grueling eight-hour train ride which was followed by a crossing to Portsmouth, England and an overland trip to Liverpool where migrants would board a ship bound for Canada. The arduous nature of this journey may help to explain why recruiting emigrant workers for Canada from areas like FGV in the late 1800s had limited success. As Grossutti notes, "in the last decades of the nineteenth century, there were very few Friulians moving to Canada." 21 Italian authorities reported only fourteen from 1876 to 1878 ; only thirty-one from 1879 to $1902 .{ }^{22}$

At the turn of the century, Friulians entered Canada by means of the padrone system, in this case a padrone was a recruiting agent hired by steamship companies which in turn had been retained by the Canadian Pacific Railway to find labourers for Canada's national railroad. By 1904 letters were making their way back to Friuli discouraging anyone from coming to Canada; labour unrest and interruptions in wages seemed to curtail arrivals but this curtailment was relatively brief. As Grossutti notes, "the [prospect] of earnings guaranteed by railway labouring still seemed higher than those offered by a working season in Europe" so that in "... 1906 and especially in the two years 1912-1913" sudden rises in emigration were recorded. ${ }^{23}$ In those years two areas of frontier employmentone by the CPR across Canada and the second in British Columbia's coal mines-meant that men from every region of Italy, not just Friulians, were attracted to Canada. ${ }^{24}$

\section{The Database and the Sample Study}

Continuing the work he first began with the archives of the Crowsnest Pass Coal Company and similar collections, Gabriele Scardellato has since collaborated with Roberto Perin to produce a 328-entry database file of emi-

21 Grossutti, Emigration, 2.

22 Grossutti, Emigration, 2.

23 Grossutti, Emigration, 10.

24 Scholarship on this topic originates from Gabriele Scardellato's work on Friulians in Trail, B.C., outlining arrivals from Codroipo, Sedegliano, Spilimbergo, San Vito al Tagliamento, Flaibano and Zoppola, as cited in Grossutti; see also Scardellato, "Friulians ...," 108-109. 
grants from Zoppola from Ellis Island records-a subset of a much larger list of Friulians emigrating to British Columbia that Perin and Scardellato are compiling. What emerged initially from this collection of 328 records was evidence of trips taken between 1906 and 1923 by a group of men, all of whom declared their birthplace as Zoppola, Udine, Italy. For Scardellato and Perin, the work represents ongoing original scholarship on emigrants from northeastern Italy while for the current study it represents an opportunity to elaborate on echoes of the author's family emigration history.

The author's father and mother, Giovanni and Rina Colussi, both originate from the town of Zoppola and they immigrated to Toronto respectively in 1954 and 1955. The family's stories include, for example, the voyage of Giovanni Colussi's uncle, Giacomo Querin when he was 24 years old. He was described as a miner and he left his father, Luigi Querin, in Zoppola (Udine, Italy). On 14 September 1920 he sailed from Boulogne-Sur-Mer aboard the SS Ryndam to join his cousin, Valentino Cecco, at the General Chemical Co., in Bay Point, California. Giacomo's son, Rudy, one of Giovanni Colussi's first cousins, still lives in the area. This particular story fits Grossutti's evidence, as noted earlier, of Friulians migrating during the 1920s and 1930s to San Francisco where the largest group was formed by families from both east and west of the Tagliamento River in FVG, including Zoppola. Families followed one another through chain migration with their port of entry at Ellis Island. Even with the expectation of arriving where there were familiar faces, these emigrants faced the daunting task of travelling from New York to San Francisco, a rail distance measured coast to coast of roughly 5,500 kilometres.

The database entries show that those passengers who entered North America via Ellis Island declared themselves to be labourers and miners who were headed for the farthest-most reaches of Canada, on its western shore in British Columbia. In his description of Italian migration to Canada, historian Franc Sturino notes that in "... the early part of the [twentieth] century, Italian sources show a higher number of emigrants destined for Canada than were recorded by Canadian immigration officials. Since New York was by far the most important port of disembarkation at this time, it is likely that a considerable number of immigrants originally bound for Canada remained in the United States." 25 Evidence from the Zoppolani database described above, however, shows without doubt that this group of over 300 emigrants entered at Ellis Island and did travel to their final destination(s) in British Columbia. Just how they arrived

25 Sturino, "Italians." 
and why such large numbers emigrated prior to, and immediately following the First World War can be thought of as both amazing and curious and so more than worthy of scholarly inquiry.

Few details are known in the current generation about this particular emigration episode to western Canada, but reference to fifteen or so departures to Argentina in 1878 is made in the "official" overview in the 100year history of Zoppola. ${ }^{26}$ In the author's immediate family, there is anecdotal knowledge of emigration out of Zoppola concerning one of the author's maternal uncles. Ellis Island records indicate that Ernesto Perin, 27 aged 24, set out for Vancouver, British Columbia on 12 August 1912 on the SS Moltke, which departed from Genova. He was sponsored by his brother-in-law, Sante Babbuin. His son Doro Perin, is in possession of all extant documentary evidence for this journey. Doro Perin's interest in that story facilitated a family reunification in 1982 and the reconnection with Friulian family members both in the Greater Toronto Area and in Italy.

Zoppolani today are most familiar with the phase of emigration that followed World War II, in particular that which took place over the decade from 1950 to 1960 and which was concentrated in the Greater Toronto Area (GTA). For some who ended up in the GTA after World War II, the road to Ontario began with emigration to British Columbia; an echo, perhaps, of the group's pre-war emigration history. Since Ontario was booming in the 1950s, however, the trip to BC was a short-lived experience and many chose to join their wider circle of paesani (townsfolk) in Ontario. The original group of post-World War II Toronto Zoppolani comprised 65 men and women. Some arrived still unmarried (as singles who would sponsor other siblings); others arrived as single married men (with sponsored wives and children to follow) and some arrived as couples. Married couples included pairings of husbands and wives who were both from the town of Zoppola itself while others included one spouse from Zoppola but a partner from a hamlet within the wider municipality. When the Zoppola Club of Toronto was founded in 1968, membership included only those from the actual town of Zoppola (not the participating hamlets within the municipality) and participation in the original club was strictly determined by geography and the boundaries of the main parish in the municipality. Subsequently, "hamlet" clubs were created, mirroring the one from the actual town of Zoppola. The existence of multiple clubs in those years was a sustainable activity when families were young and numerous. In the

26 Centanni di Zoppola, 8.

27 No relation to the historian Roberto Perin. 
1980s, however, as families began shrinking and second-generation, Canadian-born children grew up and assimilated into local Canadian circles, an effort was made to merge those clubs under the umbrella club known as "La Castellana," whose membership and loyalties are the entire municipality of Zoppola.

While this post-WWII emigration is replete with stories of courage, strength and personal sacrifice, stories from the early 1900s are those that are often unknown and neglected, particularly in emigrant families themselves. What fuelled the determination of sojourners from Zoppola during those years and underwrote their quest is very difficult to comprehend; for many, simply implausible; for others, for whom history at best is irrelevant, the story is useless. Still, it is a powerful and important undertaking for this researcher to fill in the blanks and to contextualize those early journeys. The voyages themselves were sagas; in order for these men to reach their BC destination, where they would be greeted by difficult and grueling work, they would have had to travel for a significant period of time and the exercise of retracing their route from the northeast coast of the United States to the southwest coast of Canada without the benefit of oral histories and personal accounts and similar primary sources is both challenging and exhilarating.

\section{Ship's manifest and related documentation}

Between 1880 and 1930, according to the Ellis Island website, close to 26 million immigrants arrived in the USA, mostly through the newly opened Ellis Island facility. The new facility made possible a shift in operations from Castle Gardens, at the tip of the island of Manhattan, to receive ships carrying emigrants to Ellis Island, located immediately west of Manhattan and north of Liberty Island.

Ships' manifests ${ }^{28}$ are extraordinary documents which yield crucial information about a ship's passengers and the connection between their points of departure (including those whom they left behind) and intended destinations (including those whom they declared as contacts at their destinations). The original manifests were destroyed in the early 1990s but not before they had been copied on microfilm. These microfilms have been transcribed by volunteer members of the Church of Latter Days Saints and the partial transcriptions, together with images of the original manifest pages, have been made available online. The Ellis Island online archive provides access to both a relatively brief transcription of the passenger record as well as an image of the original ship manifest (either complete or par-

28 Passenger lists which existed starting in 1880 and until the creation of passports. 
tial) which may be enlarged for viewing. Since the original ship manifest provides a greater spectrum of information beyond just names, ages, dates of travel and destinations, it is possible to build a body of information for each migrant which includes travel companions, travel clusters, and "contacts" at the named destination. To that end, the database profiles for the group that is the focus of this study comprise the following items of information: Full name (surname, first name); Ship and Port of Departure, Date of Arrival (year, month, day); Line number in Manifest, Declared Occupation; Age; Gender; Marital status; Birthplace; Contact (full name) at destination; and Previous sojourning.

\section{Methodological approaches and analysis}

On the basis of the information described above, the present study could undertake two research approaches: one quantitative and the other qualitative. Quantitatively, it is possible to summarize the voyages statistically to provide a snapshot of this 1903-1923 migration period by considering, for example:

- the total number of individuals who migrated, and their age and gender

- who left alone; who left as a family

- the typical ports of departure

- the typical ships of the time and the frequency of trips

- the occupations normally declared by migrants and

- the destinations reported for British Columbia.

Qualitatively, two types of analysis were required. On the one hand, the content of the archival material had to be evaluated according to its accuracy and validity. It was necessary, therefore, to scrutinize the information provided with a view to identifying and correcting likely spelling errors and possible misinterpretations of the names of both emigrants and the places with which they were associated. On the other hand, the archival material also required interpretation to be able eventually to reconstruct accurate departure and voyage narratives.

To this end an analysis was undertaken of the surnames recorded and their presumed point of origin. The purpose of this correlation was to distinguish between those whose point of departure was the town of Zoppola itself and those who originated in a hamlet within the municipality of Zoppola. This distinction is essential because the identities and loyalties of families and clans tended to derive from their geographical point of origin, often associated with the local church. Hence, the term campanilismo, the association inhabitants make with their town as represented by the bell tower of the local church or campanile. This phenomenon is only loosely comparable to fine-tuning the designation of Toronto as point of origin 
from more specific neighbourhood descriptions like North York, East York and Weston. In migration analysis the distinction is required in order to locate living descendants who, potentially, may be in a position to provide additional information concerning the voyages of their forbearers through oral interviews. Another essential aspect of the voyage narrative is to understand who sponsored the emigrants. Where possible sponsorship connections have been outlined to determine who were identified as sponsors: siblings, uncles; true or pro-forma friends; and clergy.

While extraordinary in their own right, as extant records of voyages, these Ellis Islands archival sources, in fact, are not robust documents. The ship manifests vary according to the type of column form used and, in so doing, may only be available as one page (either the right-hand or left-hand page of the entire ship manifest, but not both pages). The form in which information was recorded also varies significantly. Because of the shipping line and the voyage year, it can shift from longhand calligraphy, to standard calligraphy stamps, to block letter stamps, to typewritten entries. Entries are often inconsistent, incomplete, or illegible and unintelligible. In other words, working with these documents is not simply a matter of consulting the original manifest and extracting relevant data. The work involves solving a puzzle. For assistance in this task, new internet resources are now available including a variety of search engines and online registries. The resources found to be most appropriate for resolving questions produced by the manifest records include www.cognomix.it (an Italian surname search engine); www.whitepages.it and its Canadian counterpart, www.whitepages.ca; www.virgilio.it with its online telephone book, and www.Italia.indettaglio.it which offers information about Italy, its regions, provinces, cities, zip/postal codes, and surnames. ${ }^{29}$ These internet sources allowed verification of existing surnames, whether they currently exist in Friuli-Venezia Giulia and, if so, where exactly in the region they exist according to the comune in which they appear. In order to determine whether there may be an existing trace of these initial emigrants - that is, those who may have remained as immmigrants - current British Columbia online telephone and address records were consulted. All of this research helped to correct misinterpretations or incorrect spellings. ${ }^{30}$

29 Ancestry.com is not included here because of the restrictions it imposes on its users which limit them to individual genealogical research. This online resource is a type of genealogical portal that provides access to a variety of resources including Census and Voter Lists, Birth, Marriage and Death certificates, Immigration and Emigration databases, Newspapers and Periodicals, Court, Land, Wills and Financial documents and so forth.

30 It is interesting to note that ancestry.com tries to fill in gaps by offering inter- 


\section{Orthographic challenges and spelling variations}

According to information provided by Ellis Island experts, a myth persists that government officials compelled immigrants to take new names against their wishes. In fact, historical records do not bear this out. Federal immigration inspectors were under strict supervision and were more interested in preventing inadmissible aliens from entering the country (for which they were held accountable) than in assisting them in activities like altering their names. The inspectors used the passenger lists given to them by the steamship companies to process each foreigner. These were the sole immigration records for entering the country and were prepared not by the United States Bureau of Immigration but by the steamship company themselves. While in some cases surnames were "Americanized" by the family after the immigration process or by the second or third generation of the family after some assimilation into American culture, many last names were altered due to the disparity between English and other languages in the pronunciation of certain letters of the alphabet. ${ }^{31}$

As was to be expected, where the Zoppolani were concerned, names were often altered probably because of linguistic incomprehension on the part of the recording official. As mentioned earlier, the constant challenge is to be able to interpret the calligraphy of the handwritten documents. Moreover, what might at first seem correctly "edited" in its online transcibed form may, in fact, create further confusion. Those entries must also be cross-checked against an "existing" surname. One case of this type was the entry in the Zoppolano database which, based on the original ship manifest, appeared as "Da R..." (where only the top left hand corner of the letter ' $R$ ' was actually visible). The online version of the ship manifest transcribed the name as "Da Bon" as the correct solution. In fact, no such surname exists in Italy, let alone in FVG or Zoppola. Rather, the common surname from the latter area is "Da Ros." A careful analysis of the original entry suggests the letter ' $\mathrm{R}$ ' rather than the letter 'B.' Moreover, a search of current Zoppola White Pages indicates the existence of one "Da Ros" surname while in the adjacent Pordenone area twenty-one "Da Ros" surnames appear. "Da Ros" is clearly the most plausible and appropriate interpretation based on existing residential records. (See the author's correction in the last entry listed in Sample 2 below). What follows are representative examples of the variations in places and surnames:

pretations based on related entries. I was able to correct what appeared as missing letters in a particular surname by consulting existing surnames in FVG.

31 www.wikipedia.com accessed 15 March 2010. 
Sample 1

\begin{tabular}{|l|l|}
\hline $\begin{array}{l}\text { Zoppola } \\
\text { appears as }\end{array}$ & $\begin{array}{l}\text { Zappola, Zappolo*, Zoppora, Zappula, Zoppla, Zappsla, Goppola, } \\
\text { Loppola, Fappola**, Zoppota***, Yoppola**** }\end{array}$ \\
\hline
\end{tabular}

*Zilli, Luigi; 24 Mar. 1914; (Rochambeau) ; typed Passenger List, Ellis Island

**Cassin, Angelo; 27 Mar. 1911 (Duca degli Abruzzi); typed individual Passenger record; Ellis Isand

*** Cassin, Antonio; 24 Mar, 1914 (Rochambeau); typed individual Passenger record; Ellis Isand

****Ircandia, Giovanni; 22 Apr. 1912; (Rochambeau); Ellis Island typed Passenger record;

Sample 2

\begin{tabular}{|l|l|}
\hline Udine appears as & Adine \\
\hline Pagura appears as & Pagnra \\
\hline Ermenegildo & Emiengildo \\
\hline Bortolussi appears as & Bortoluzzi \\
\hline Cranbrook & Cambrook (probably as pronounced) \\
\hline Da Ros, Guglielmo & $\begin{array}{l}\text { Da B. Gagbalino (online transcription is Da Bon, } \\
\text { but neither the B nor the next 2 letters are legible in } \\
\text { the microfilm) }\end{array}$ \\
\hline
\end{tabular}

Numbers of migrants according to year of travel

Table 1 indicates the year-by-year mobility of the group and confirms what historians have observed concerning the highs and lows of Italian emigration; in this case, the interruption associated with Italy's entry into WWI in 1915 and the end of the war in 1918. By 1919, the pace resumed but interruptions occurred again in 1921 and 1924. It would seem that the enactment of immigration restrictions by the USA in 1924 in the form of an annual quota for Italy of 3,845 persons had a significant impact on departures from Zoppola as elsewhere in Italy.

Table 1

\begin{tabular}{|c|l|l|l|l|c|c|c|l|l|}
\hline 1903 & 1904 & 1905 & 1906 & 1907 & 1908 & 1909 & 1910 & 1911 & 1912 \\
\hline 1 & 11 & none & 70 & 70 & 1 & 1 & 28 & 23 & 24 \\
\hline 1913 & 1914 & $1915-18$ & & 1919 & 1920 & 1921 & 1922 & 1923 & 1924 \\
\hline 36 & 30 & none & & 2 & 1 & None & 3 & 25 & none \\
\hline
\end{tabular}

The total number of migrants over this twenty-year period (1903-1923) is 328 with 1906 and 1907 representing 43\% of the total number of arrivals at Ellis Island. According to Ellis Island migration flow statistics, 1907 rep- 
resents the peak year for all arrivals with a grand total of over one million migrants received $(1,004,756)$. The all-time daily high in that year occurred on 17 April when a total of 11,747 emigrants were processed. 32 While this is not the specific date on which the northeastern Italians arrived, the database shows that Zoppolani entered Ellis Island on eight different occasions that year, declaring Marysville, Michel, Cranbrook and Yahk (in the Crowsnest Pass area), in other words, mining towns in British Columbia, as their destination(s).

\section{Vessels and ports of departure 33}

At first glance, details about the ships which transported emigrants may seem trivial or easily reduced to statistical tallying; from the qualitative perspective, however, knowledge about them is invaluable. Ships themselves often became the central characters in voyage narratives and they appear in personal letters and in works of creative non-fiction and fiction. For the moment, the database offers a quantitative perspective provided by tracking groups of departures vessel by vessel; typical ports of departure and changes over the twenty-year period. While we are unable to corroborate it here, it may be that at the time local steamship companies established rights of entry or docking at particular ports. Access to and use of particular ships would most likely have been determined by market conditions and ocean worthiness of the vessels. What is known, however, is that new train lines out of Friuli would have made it possible to reach even the farthest departure ports.

The highest concentration of voyages occurred between 1904 and 1914 when $85 \%$ of the group travelled. In this first decade, the preferred port of departure was Le Havre. After WWI, it is clear that travel from this port ceased and shifted instead to Italian locations.

Table 2

\begin{tabular}{|l|l|c|}
\hline $\begin{array}{l}\text { Port of } \\
\text { Departure }\end{array}$ & Ship & $\begin{array}{l}\text { Total number } \\
\text { of travellers }\end{array}$ \\
\hline Le Hâvre & $\begin{array}{l}\text { SS La Savoie 1904 (10);1906 (18), 1907 (13); } \\
1910(5) ; 1911(9) ; 1912(9) ; 1914(1)\end{array}$ & 65 \\
\hline
\end{tabular}

32 See the timeline provided on the EllisIsand.org website http://www.ellisisland.org/genealogy/ellis_island_timeline.asp

33 An important resource for viewing shipping lines and ships is available at the website www.theshiplist.com/ships/lines. This site also offers information on immigrant ships. Website creator and webmaster: Louis S. Alfano 1997-2006, consulted on 30 September 2010. 


\begin{tabular}{|c|c|c|}
\hline & $\begin{array}{l}\text { SS La Lorraine } 1906 \text { (5); } 1907 \text { (15); } 1910 \text { (8); } \\
1913 \text { (18 }\end{array}$ & 46 \\
\hline & SS La Gascogne 1903 (1); 1906 (25); 1907 (15) & 41 \\
\hline & $\begin{array}{l}\text { SS La Touraine } 1906 \text { (22); } 1907 \text { (3); } 1910 \text { (3); } \\
1911 \text { (7) }\end{array}$ & 35 \\
\hline & SS Rochambeau 1912 (12); 1914 (18) & 30 \\
\hline & SS Chicago 1909 (1); 1910 (12); 1913 (5); 1914 (3) & 21 \\
\hline & SS La Provence 1906 (4); 1907 (16) & 20 \\
\hline & SS La Bretagne 1907 (13) & 13 \\
\hline & SS La Liguria 1907 (10) & 10 \\
\hline & SS France $1914(7)$ & 7 \\
\hline & SS Verona 1914 (2) & 2 \\
\hline Total depar & res between 1904 and $1914=260$ & \\
\hline
\end{tabular}

Table 3

\begin{tabular}{|c|c|c|}
\hline $\begin{array}{l}\text { Port of } \\
\text { Departure }\end{array}$ & Ship \& Year(s) \& Numbers of Departure(s) & $\begin{array}{l}\text { Total number } \\
\text { of travellers }\end{array}$ \\
\hline \multirow{15}{*}{ Genova } & SS Città di Napoli 1904 & 1 \\
\hline & SS Duca d'Abruzzi 1908 & 7 \\
\hline & SS Prinzess Irene 1910 & 1 \\
\hline & SS Duca degli Abruzzi 1911 (5); 1919 (2) & 7 \\
\hline & SS Moltke 1912 & 3 \\
\hline & SS Stampalia 1913 & 2 \\
\hline & SS Europa 1913 & 9 \\
\hline & SS Verona 1914 & 2 \\
\hline & SS Taormina 1923 & 2 \\
\hline & SS Duilio 1923 & 1 \\
\hline & SS Conte Rosso 1923 & 13 \\
\hline & SS Conte Verde 1923 & 5 \\
\hline & SS Giulio Cesare 1923 & 2 \\
\hline & SS Giuseppe Verdi 1923 & 1 \\
\hline & SS America (ship 1908) in 1923 & 1 \\
\hline aep & $\begin{array}{l}s \text { between } 1904 \text { and } 1914 \text { from Genova }=20 \\
\text { ver } 10 \text {-year period). }\end{array}$ & \\
\hline
\end{tabular}

Comparing Tables 2 and 3, it is clear that before WWI, the most frequent port for departures was Le Havre, France which is very intriguing and again, may be linked to the activities of a steamship company and its local 
representatives. Clearly, the trip to the French coast was longer and presumably entailed greater costs than a journey to an Italian port. Only $4 \%$ of the group chose Genova in that first decade of travel. The greatest concentration for departures out of Genova occurred after WWI and, in particular, 1923 with 25 departures (or $8 \%$ of the total) from that location alone.

Table 4

\begin{tabular}{|l|l|l|}
\hline Genova/Napoli (two-port stop) & SS Colombo 1922 & 2 \\
\hline Naples & SS San Giovanni 1913 & 2 \\
\hline Napoli & SS Italia 1920 & 1 \\
\hline Trieste & SS Martha Washington 1923 & 1 \\
\hline
\end{tabular}

Table 4 shows other routes and ports. Naples was the choice, in 1913, for only two travellers, with an additional departure by a Zoppolano from there in 1920. In 1922, a two-port stop was indicated while the port of Trieste appeared only once, in 1923, as a point of departure.

\section{Travel companions / Travel clusters}

In the Centanni di Zoppola, reference is made to the impact of immigration abroad and its effect on families. As we know from gender and age profiles, ${ }^{34}$ those who migrated to North America included single males in their late teens or early twenties; young married males in their twenties; and both married or single older males. Overall ages ranged from 15 to 40 . Not only does this database corroborate those profiles but it was often the case that older males travelled as well. For example, of the four Zoppolani who travelled on 17 August 1907, Luigi Mussio (40M35) was travelling to meet his brother in law, while Osvaldo Mussio (45M) named his son as his destination contact.

Over the twenty-year period, migrants were normally males and tended to travel in groups or clusters, rather than alone. In larger groups (comprising anywhere from ten to seventeen persons) there could be sub-clusters of family members (such as brothers or siblings). Over this twenty-year period only 6 females travelled, in pairs and with explicit kinship bonds. The first of these voyages occurred in April 1906 when Luigia Pighin (24M) travelled to join her husband, Angelo, with her sister-in-law Maria

34 Nelli, "Italians," 545-560; Ramirez, The Italians, Vecoli, “The Italian Diaspora." 35 Henceforth, capital $M$ and capital $S$ next to the given ages signify "married" and "single," respectively. 
Pighin (16S) who would reunite with her brother Angelo. The second voyage took place in October 1906 when Angela De Giusti Pighin (24M) and her two-month-old daughter Maria, travelled to meet their husband and father, Giovanni Pighin, in Marysville, B.C. The third voyage was undertaken in November 1919 by Marina (20S) and Vilma (15S) Narduzzi, sisters who travelled with the declared occupation of "domestics" to join their father Attilio, in Michel, B.C..

A further analysis of the total number of yearly departures according to departure dates and the number of travellers by group indicates that in any given year voyages varied in number, frequency, and group size. In 1906, for example, seventy townsfolk departed on thirteen different occasions from Le Havre alone. These departures ocurred respectively according to the following seasonal distributions: 1 in the spring; 4 in the summer and 8 in the fall (with 5 in October and 2 in December). On 21 October, a single male departed; the day following, on 22 October, ten departed together. In 1907, 11 departures, averaging seven persons each, were recorded: 4 in winter, 3 in spring (April), 3 in summer and 1 in fall. From 1910 to 1914 , the frequency of voyages to Ellis Island that included Zoppolani dropped to between 4 and 5 departures in each year. In 1923, the last year of the period surveyed, 11 departures took place: 1 in the winter, 3 in the spring, 6 in the summer and 1 in the fall and on average during this year only two persons travelled per voyage. In the second to last departure in 1923, six (apparently) unrelated single males between the ages of 17 and 29 travelled together. The males in the Fabbro clan, however, mostly in their teens or early 20 s were attracted to migrating and had little concern about voyaging alone.

\section{Challenging Narratives}

One component of the current study involves an analysis of the contacts named by emigrants to reveal the relationship between the traveller and his or her contact or sponsor. In order to illustrate the challenges encountered in this research two cases drawn from the 1906 group of Zoppolani emigrants will be discussed in detail. The first is an example of a straightforward story of brothers who sojourned for economic prosperity, with changes in destination during their travels. The second is an extremely complicated story, yet to be unravelled completely, of mistaken identities among sponsors and contacts.

\section{The Pighin Case}

The travel network established by Pighin family members begins with Angelo Pighin, a married, 28-year-old male, who departed from Le Havre on SS la 
Savoie and arrived at Ellis Island on 19 March 1904, headed for Michel, B.C. It seems that employment prospects in British Columbia were hopeful because on 9 April 1906 two of his brothers departed on SS la Gascogne from Le Havre and both declared their "brother" Angelo as their contact: Antonio Pighin was 18 years old and single while Giovanni was 28 and married. Here the destinations indicate that within the space of two years, the work available may have shifted. While Angelo had declared Michel, B.C. as his destination, Giovanni and Antonio were both headed for Marysville, B.C.

\section{The Cantarutti Case}

When he departed on SS la Liguria from Genova on 22 April 1907, Mano Martin (23S) declared as his contact in Marysville a certain Giacomo "Pontarutti" or "Castarutti," neither interpretation legible because of poor calligraphy in the original manifest record. In fact, neither "Pontarutti" nor "Castarutti" exist as typical last names in the Zoppola area. Rather, he was most likely a Cantarutti, especially since two other males from the Cantarutti clan travelled during that period: one in 1906, Isaia Cantarutti (19S); and the other in 1910, Luigi Cantarutti (28M). So who might the contact-Giacomo Cantarutti-named by Mano Martin have been and is it possible to trace the arrival of this Cantarutti emigrant?

In an effort to resolve this question the Ellis Islands records were searched for someone who had arrived in the months and year(s) before Mano Martin in April of 1906 but a search for Giacomo Cantarutti in that relatively early period of Zoppolano emigration yielded no results. Rather, my search uncovered two other Cantaruttis, both of whom travelled in 1913, so long after the voyage by Mano Martin, and both of whom had not been recorded in the original database because their destinations were not located in British Columbia:

1) Giacomo Cantarutti (32M), from Castions, [Zoppola], Udine; 5 March 1913, travelling on SS America; contact Giovanni Fabbro; leaves behind an unnamed "wife" in Castions. 36

2) Giacomo Cantarutti (16S) from Coseano/Coscano [sic Cusano, i.e. Zoppola] 31 March 1913, (but amended to 2 April 1913) on SS Rochambeau from Le Havre and headed for Edmonton, Alta. and named as his contact at his destination, Giovanni Ferrazzutti. ${ }^{37}$

36 SS. America, 5 March 1913; voyage of "Giacomo Cantarutti”, (32M), manifest line 21.

37 SS Rochambeau, 31 March 1913; voyage of "Giacomo Cantarutti", (16M), manifest line 17. 
An attempt to corroborate this information with other online resources only produced further complications. According to another version of the manifest for SS America, ${ }^{38}$ someone called Giacomo Cantarutti, 32 years old, arrived on that ship from Genova, Italy on 5 March 1913. He left behind his father Angelo Cantarutti in Castions, Udine (not his wife) and his final destination was reported as Medicine Hat, Alberta (not Edmonton). The two versions of the ship manifests consulted appeared to be identical but the information they provide is contradictory. Unfortunately, the online Ellis Island version of this manifest for SS America produces the record for another ship entirely; the SS Kaiser Wilhelm which sailed from Bremen, Germany on 8 April 1913. This entire line of inquiry leads to a dead end; this is not the Giacomo Cantarutti who might have been Mr. Mano Martin's contact in 1906.

The Ellis Island records, however, include a listing for a certain "Giacoma" Cantarutti which is clearly a transcription error since there exists no such first name in Italian for either males or females. This 25year-old, married male arrived on SS La Savoie from Le Havre on 19 May 1906 and because his profile fits the date criteria being sought this traveller could be the person who was named as Mano Martin's contact in British Columbia. A closer examination of the ship's manifest, however, did not yield the information hoped for since, rather than indicating British Columbia as his final destination, this "Giacomo" is part of a group of male "labourers" from Zoppola who were headed for Brooknea (Brooke) County and the coal mines in West Virginia. This search, however, also produced a listing for a certain Igioia Cantarutti (15S), one of the males travelling with the aforementioned "Giacomo" on 19 May 1906. Igioia's travel companions included Isaia Fabbro Fragona (22S) and Francesco Fabbro Fragona (18S) described as "brothers" on the manifest. They are among those stamped "non-immigrant alien" which normally indicates individuals transiting through the USA and not intending to remain in the country of arrival. Once again, however, and despite their designation as "non-immigrant alien," these brothers are not headed for a destination in British Columbia but rather for Edri, Pennsylvania.

The Cantarutti search does lead eventually to a voyage undertaken on 27 March 1920 when a certain Igioia Cantarutti arrived at Ellis Island on his way to "Croombrok, Can" to meet his friend "Pagusa [but probably Pagura], Isidoro." In the column recording whether the passenger had ever before been "... in the US and if so, where and when?" the clerk compil-

38 America was the name of a vessel also known as the SS The America (1908). 
ing the manifest noted "Yes, 13/16" (presumably then from 1913 to 1916) but where? His previous stay is written as "Aug, Pa," no doubt a location in Pennsylvania. The 1920 manifest reports that he was "IN TRANSIT" with a fellow traveller, 24-year-old Luigi Benvenuti and his final destination was entered as "Can, Cranbrook." This Igioia, now married, had left his wife Santa behind in Zoppola and, based on a calculation of his age in 1920 this could be the same Igoia who had arrived at Ellis Island in 1906 as a 15-year-old, single male. In support of this possibility there is also a British Columbia record for the death of Igioia Cantarutti in Trail, B.C. at 82 years of age. 39

The description of this extremely challenging Cantarutti search raises important analytical issues. By declaring that he had previously been in the USA from 1913 to 1916 but not in 1906, this Igioia seems not to be the same person but there is a curious link between the 1906 passenger, the 1920 passenger, and the British Columbia death record. 40 An Igioia Cantarutti did remain in British Columbia until his death and it is fair to say that "Igioia" is a very unusual Italian male given name. Available information about Cantaruttis in Toronto might allow us to pursue this immigration narrative through an oral history investigation. Furthermore, it is vital to begin examining the relationship between mining destinations such as Brook County, West Virginia and Edri, Pennsylvania ${ }^{41}$ in the USA since they may turn up a series of work stops on route to British Columbia.

\section{Destination: Southern British Columbia}

Over the twenty-year period of this study certain destinations in British

39 The entry in the British Columbia registry of deaths reads "Igioia Cantarutti, Gender: Male Age: 82 Death Date: 16 Jul 1973 Place of Death: Trail.”

40 It is possible that passengers only declared (or that the steamship clerk only recorded) their last sojourn or transit through the USA; that is, they were not required to provide a complete history of their migration(s) to destinations in North America.

41 There is much to be investigated here for possible connections between American and Canadian destinations and eventual settlements. See, for example, the history of early coal mining in Brook County, West Va.); www.polsci.wvu. edu/wv/Brooke/brohistory.html; also, the Memorial to Italian coal miners at Edri, PA, who died in the mines, 1903-1919; www.patheoldminer.rootsweb. ancestry.com/indedri1.html; see also the story of the Wheelwright, Kentucky mines www.coaleducation.org/coalhistory/coaltowns/ wheelwright. htm e.g, a certain Cantarutti, Guiseppe [sic, Giuseppe] travelled from Antwerp on the Kroonland on 6 July 1920 destined for Kentucky. 
Columbia became increasingly attractive for Zoppolani emigrants as economic opportunities in the province expanded. According to Scardellato, this area became one of the many "labouring frontiers" of Canada's early mass migration. In British Columbia in these years, a burgeoning demand for labour emerged based on the continuing expansion of the Canadian Pacific Railway and the arrival of a variety of American and Canadian adventurers and entrepreneurs who took advantage of the discoveries of gold, coal, and other resources. The labour required for the exploitation of these commodities as well as the development of various forms of infrastructure was satisfied, in part, by those documented in this study.

By 1923 then, a number of British Columbia destinations can be extracted from the Ellis Island records. In terms of the greatest number of times that a destination was reported these were, in order of decreasing frequency; Michel (116), Marysville (51), Cranbrook (59), Vancouver (18), Wycliffe (12), Grand Forks (9), Trail (7), Kimberley (6), Kelowna (5), Fernie (4), Sicamous (4), Yahk (4), Penticton (3), Wardner (3), Revelstoke (2), Hope (2), Merritt (1), Nelson (1) and on the Pacific Coast, north of Vancouver, Powell River (1) and much further north, Prince Rupert (1). In turn, these settlements can be re-grouped as regional geographical clusters. These clusters are distinct from each other because of their respective economies and the employment opportunities they provided for Zoppolani and others, as well as their connections to local transportation systems and similar factors. According to these criteria, Zoppolani emigrants to British Columbia can be said to have targetted mainly two relatively distinct regions; the Fernie-Michel region (120 emigrants) and the Cranbrook-Marysville region (141 emigrants). Between them these two geographically adjacent regions represent more than three-quarters (79\%) of all Zoppolano journeys to British Columbia by the early 1920s according to the ships' manifests. A glimpse into the histories of these towns and their regions reveals their attraction as places for employment in mining, lumbering, railway expansion and similar activities.

Fernie was developed just west of the vast Crowsnest coal field by the nineteenth-century prospector William Fernie, who established the coal industry there that continues to this day. He created the Crows Nest Pass Coal Company in 1897 and created a temporary encampment near Coal Creek. While no mining ever took place in Fernie proper, the processing of coal from Coal Creek was carried out in coking ovens in Fernie and, as a result, the settlement developed into an administrative and commercial centre for an industry that was growing by leaps and bounds. Moreover, the Canadian Pacific Railway arrived in the valley in 1898 and a town site 
emerged parallel to the railway line slightly north of the initial encampment, or "Old Town." In the early 1900s, underground coal mines were dug in the narrow Coal Creek valley ten kilometres away and a variety of other mines were sunk into the coal fields in a fifty-kilometer radius. This increased significantly the demand for labour which Zoppolani could fulfill and the database records corroborate the fact that the mining areas themselves, rather than Fernie proper, were the primary destinations. Fernie, for example, was declared as a destination in only four instances, twice in 1906 and twice in 1923 compared with 116 references for Michel, located in the same narrow valley but to its north and east.

Cranbrook, located on the Kootenay River at its confluence with the St. Mary's River, can be thought of as the centre of the region in the southeastern interior of the province that was even more important than FernieMichel for Zoppolano emigrants. Cranbrook was connected with Wycliffe and Marysville (and eventually Kimberley) by means of the Old Wycliffe Road. In the 1900s it was the central location for the Spokane International Railway and in the 1920s for the Canadian Pacific Railway. According to the database of Ellis Island arrivals there were fifty-nine travellers who were destined for Cranbrook, as follows:

\begin{tabular}{|l|c|c|c|c|c|c|c|c|}
\hline Destination & 1907 & 1910 & 1912 & 1913 & 1914 & 1920 & 1922 & 1923 \\
\hline Cranbrook & 10 & 9 & 8 & 14 & 11 & 1 & 2 & 4 \\
\hline
\end{tabular}

The Cranbrook-Marysville region can be extended to the south and west as far as Yahk, a prosperous CPR lumber town which provided amenities for some eighteen lumber camps and a railway tie mill and which attracted at least 4 Zoppolano emigrants, all in 1907.

The settlement of Wardner, to the south and east of Cranbrook, also might be considered part of this region. Situated on the west shore of the Bull River, this settlement dates to 1897 and the CPR's push into the Kootenays. By the early 1900s, activities turned to lumbering and related work in the local forest industry under the auspices of the Crow's Nest Pass Lumber Company. By 1910, new housing was raised for the mill workers, and in 1911 a huge iron works incinerator was built. The records indicate that three Zoppolani travelled to Wardner in those years, a certain Umberto Foneguzzi (read Toneguzzi; 1911) whose contacts were two brothers who had reached the settlement before him, Fortunato and Giovanni. Two others who travelled to Wardner, both on the same voyage undertaken in 1911, may have been brothers-Federico (18) and Cesare (21) Fabbro - and they both named a "brother" Pietro as their contact. Also included in the records are the names of two Pietro Fabbros, one aged 
21 and the other 16, who travelled in 1904 and 1906 respectively, but they were both headed to Michel where they named as their contact, respectively, a certain Osvaldo Jus and a "friend," a certain Osvaldo Fabbro. Together then, the settlements of Cranbrook itself and those in its vicinity - for example, Kimberley, Marysville, and Wycliffe and including the somewhat more distant settlements of Wardner to the southeast and Yahk to the southwest - formed the region that was the most frequently targetted destination for Zoppolani in the entire province.

The remainder of Zoppolano destinations were spread across a number of settlements which again can be grouped according to relatively distinct clusters in given geographic locations but in these instances the numbers were much smaller than those just discussed. Between them the settlements of Trail and Grand Forks, for example, a considerable distance to the west and south and much closer to the border with the USA than the Cranbrook-Marysville cluster, accounted for a total of some sixteen destination references by Zoppolani. Grand Forks is situated just north of the USA-Canada border, approximately two hundred kilometres from Spokane, Washington and is close to the site of the former Phoenix copper mine, which was active until 1935. The database indicates that in 1906 some nine Zoppolani headed to Grand Forks and a certain Elia Sartor served as a contact for these emigrants and for others who, in the same year, were headed for Michel. Between 1910 and 1923 another seven Zoppolani travelled to the settlement of Trail, possibly for employment in facilities like the large smelter that had begun operations there in the late nineteenth century.

There were a number of other British Columbia destinations named by Zoppolano emigrants in the Ellis Island records but it is difficult to group them according to significant regional clusters. Destinations like Penticton and Kelowna, for example, attracted respectively three and five emigrants, and may all be thought of as targetting a region - that is, the Okanagan Valley - given that they all travelled in 1913 to destinations not far removed from each other on the shores of Okanagan Lake. This notion of "region" in this instance might be stretched to include settlements like Sicamous (four arrivals, all in 1912) to the north and east of the Okanagan Valley and still further east Revelstoke (two arrivals, both in 1914) at the upper end of Upper Arrow Lake. The last destination to be discussed, albeit also very briefly, was named far more frequently than these last four. Vancouver, the province's metropolitan centre that emerged on its southwest coast, at the mouth of Burrard inlet, was named by a total of 18 Zoppolano emigrants and all except one of them arrived in the city before World War I. 


\section{Next steps}

Clearly, working with the types of archival records described in this case study is both challenging and intriguing. While the sample discussed offers glimpses into the narratives of the voyages of these 328 Zoppolani, there is still a vast amount to be discovered, some of which might require more than written sources. The travel and family clusters are fascinating; the economic history of the destinations and conditions for labour surrounding them equally so because they suggest motives for calling for other family members and choosing whether to return or to remain by attempting family reunification. One of the aspects of the emigration being studied which remains a mystery and represents considerable intrigue are the actual routes travelled. While Grossutti attempts to complete some of the puzzle, by outlining the journey through Paris, little is known of the local departure details and less still about the journey these emigrants faced after they disembarked at Ellis Island. More research is required on the role of train travel. 42

What is required is to broaden the research on two fronts; the first, by investigating records in Zoppola, as Grossutti did in building his story of the Pozzuolesi; the second, is to pursue further queries with the families of the Zoppolani living in the GTA or, if possible, with those who might have remained in British Columbia. In this way it will be possible to continue to fill in the gaps and by so doing to attempt to weave the narratives of this relatively unknown group in order to bridge the distance between the past and the present with the experiences of living descendants.

\section{YORK UNIVERSITY}

\section{WORKS CITED}

\section{Original sources}

Newspaper articles from Giornale di Udine (1901) and La Patria del Friuli (1903, 1904); Canadian government pamphlets such as Gustave Bossange's La nuova Francia. Il Canada, antica colonia francese. Appello alle classi operaie, Paris, Allan Lines Agent, 1873.

42 For a start on early railroad routes, see "Railroad Maps of the United States. A Selective Annotated Bibliography of Original 19th-century Maps in the Geography and Map Division of the Library of Congress," compiled by Andrew M. Modelski, 1975. Library of Congress. Website: http://cprr.org/Museum/ Ephemera/Travel.html Downloaded: September 21, 2010. 


\section{Published Sources}

Vecoli, Rudolph J. "The Italian Diaspora, 1876-1976." The Cambridge Survey of World Migration. Ed. Robin Cohen. Cambridge; New York: Cambridge University Press, 1995. 114-122.

Luchini, Luigi (ed.). 100 Anni con gli emigranti, 1907-2007. Pordenone: EFASCE, 2009.

Eisenbichler, Konrad (ed.). An Italian Region in Canada. The Case of Friuli-Venezia Giulia, Toronto: Multicultural History Society of Ontario, 1998.

Iuele-Colilli, Diana. I friulani di Sudbury. New York; Ottawa: Legas, 1994.

La Pro Loco, (ed). 2002. Cent'anni a Zoppola. Il XX secolo tra cronaca e storia. Zoppola, Italy, 2002.

Nelli, Humbert. "Italians." Harvard Encyclopedia of American Ethnic Groups. Ed. S. Hallstrom, et al. Cambridge, Mass.: Belknap Press of Harvard University, 1982. 545-560.

Peressini, Mauro. "Migration, Famille et Communauté, Les Italiens du Frioul à Montreal," Études italiennes, N. 2, Montreal: M. Peressini; Université de Montreal, 1990.

Principe, Angelo \& Olga Zorzi Pugliese. Rekindling Faded Memories: The Founding of the Famee Furlane of Toronto and Its First Years (1933-1941). Ravvivare ricordi affievoliti: la fondazione e i primi anni della Famee Furlane di Toronto (19431941). Toronto: Famee Furlane, 1996.

Ramirez, Bruno. The Italians in Canada. Canada's Ethnic Groups, No. 14. Ottawa, ON: Canadian Historical Association, 1989.

Ridolfi, Luigi. I Friulani nell'America del Nord, Udine: Arti Grafiche Cooperative Friulane, 1931.

Scardellato, Gabriele P. "Friulians in Trail, B.C.: Migration and Immigration in the Canadian Periphery." An Italian Region in Canada. The Case of FriuliVenezia Giulia. Ed. Konrad Eisenbichler. Toronto: Multicultural History Society of Ontario, 1998. 103-120.

. "Beyond the Frozen Wastes: Italian Sojourners and Settlers in British Columbia." Eds. Roberto Perin and Franc Sturino. Arrangiarsi: The Italian Immigration Experience in Canada. Montreal: Guernica, 1989. 135-162.

\section{Online sources}

Ellis Island Archives. www.ellisisland.org

"Biblioteca." Ente Friuli nel Mondo. www.friulinelmondo.com

Brook County coal mining.: www.polsci.wvu.edu/wv/Brooke/brohistory.html British Columbia towns:

Cranbrook, B.C.: http://en.wikipedia.org/wiki/Cranbrook,_British_Columbia Crownest Highway : http://www.crowsnest-highway.ca/

Fernie, B.C.: http://en.wikipedia.org/wiki/Fernie,_British_Columbia Fort Steele/Wycliffe, B.C.: http://files.fortsteele.ca/history/photos/Wycliffe.asp Grand Forks : http://en.wikipedia.org/wiki/Grand_Forks,_British_Columbia Hope, B.C.: http://en.wikipedia.org/wiki/Hope,_British_Columbia Kimberly, B.C. : http://en.wikipedia.org/wiki/Kimberley,_British_Columbia 
Marysville, B.C.: http://www.ourbc.com/travel_bc/bc_cities/bc_rockies/kimberley.htm

Merritt, B.C. : http://en.wikipedia.org/wiki/Merritt,_British_Columbia

Penticton, B.C.: http://en.wikipedia.org/wiki/Penticton

Revelstoke, B.C. : http://en.wikipedia.org/wiki/Revelstoke,_British_Columbia

Sicamous, B.C.: http://en.wikipedia.org/wiki/Sicamous,_British_Columbia

Wardner, B.C.: http://www.crowsnest-highway.ca/cgi-bin/citypage.pl?city= WARDNER

Yahk, B.C.: http://www.britishcolumbia.com/regions/towns/?townID=3525

Ente Friuli Assistenza Sociale Culturale Emigranti (EFASCE); www.efasce.it

Grossutti, Javier, "Emigration from Friuli Venezia-Giulia to Canada"; retrieved as pdf 29 August 2010. Publication itself is undated and pages are unnumbered; page references inserted by author. www.ammer-fvg.org/_Data/Contenuti/ Allegati/ eng/en_ grossutti_canada.pdf, page 2.

—. "Emigration from Friuli-Venezia Giulia towards the United States"; retrieved as pdf 29 August 2010, publication itself is not dated in original.

Italian surname search engine: www.cognomix.it

Modelski, Andrew M. "Railroad Maps of the United States. A Selective Annotated Bibliography of Original 19th-century Maps in the Geography and Map Division of the Library of Congress Library of Congress." 1975. http://cprr.org/Museum/Ephemera/Travel.html; retrieved 21 September 2010.

Memorial to Italian coal miners at Edri, PA, 1903-1919: www.patheoldminer. rootsweb. ancestry.com/indedri1.html

Sturino, Franc. "Italians." The Encyclopedia of Canada's Peoples. Ed. P.R. Magocsi, et al.Toronto: University of Toronto Press, www.multiculturalcanada.ca/ Encyclopedia/A-Z/i1 1

Venetian battuto.: www.cancianpavimenti.it/battuto-alla-veneziana

Virgilio search engine and online telephone book:www.virgilio.it; www.Italia. indettaglio.it

Wheelwright, Kentucky mines: www.coaleducation.org/coalhistory/coaltowns/ wheelwright.htm

White Pages, Italy: www.whitepages.it

White Pages, Canada: www.whitepages.ca

\section{Hometown websites}

Pozzuolo, Udine, Italy: www.comune.pozzuolo.udine.it/web/uploads/pozzuolesi/www. tommasomazzoli.it/pozzuolo/index.html

Zoppola, Pordenone, Italy: http://en.wikipedia.org/wiki/Zoppola

The town of Zoppola and its hamlets: http://www.comune.zoppola.pn.it/IlPaese.3844.0.html 